\title{
SEASONAL VARIATIONS OF TRACE METALS LEVELS IN WATER AND THE LIMPET PATELLA CAERULEA OF ALEXANDRIA COAST, EGYPT.
}

\author{
Sabry S. El-Serafy', Mona M. El-Gamal ${ }^{2}$ and Dalia S. El-Sayed \\ 1-Zoology Department, Faculty of Science, Zayazig University. \\ (Benha branch). Egypt. \\ 2-Zoology Department. Faculty of Science. Tanta University. Egypt.
}

Keywords: trace metals: seasonal variations; rocky shores; Palella caerulea

\begin{abstract}
T he whole soft tissues of the Patella cuerulea from Abu-Qir, ElAnfushi and El-Mex stations in Alexandria were seasonally analyzed during the period from Autumn 200 ! to Summer 2002, to determine the levels of $\mathrm{Cd}, \mathrm{Co}, \mathrm{Cu}, \mathrm{Fe}, \mathrm{Pb}$ and $\mathrm{Zn}$ to reveal their patterns of accumulation throughout different seasons. The correlation between seasonal variations and the nature of investigated stations in metal concentrations was significant. Summer recorded the highest concentrations of $\mathrm{Cu}$ and $\mathrm{Zn}$ and the lowest one for $\mathrm{Pb}$. Winter recorded the lowest concentrations of $\mathrm{Fe} . \mathrm{Zn}$ and $\mathrm{Cd}$. while Co recorded its highest concentration in the same season. Fe recorded its highest concentration in Spring, while Autumn recorded the highest concentrations for both $\mathrm{Cd}$ and $\mathrm{Pb}$.

On the other hand, $\mathrm{Cd}, \mathrm{Pb}$ and $\mathrm{Zn}$ concentrations in water and tissues revealed highly significant differences for stations and seasons. $\mathrm{Co}, \mathrm{Cu}$ and $\mathrm{Fe}$ concentrations in water revealed marked differences for both seasons and stations. There were no marked differences between seasons for $\mathrm{Co}, \mathrm{Cu}$ and $\mathrm{Fe}$ that accumulated in the soft parts of Patella tissues, while stations were significant. The highest values of $\mathrm{Cd}$ and $\mathrm{Pb}$ was reported for samples collected from El-Mex in Autumn, while the highest ratio of $\mathrm{Cu}$ was revealed for the same station but in Summer. The highest concentration of $\mathrm{Co}$ appeared in Autumn from El-Anfushi, while its lowest concentration during the same season was in Abu-Qir. Fe recorded its highest concentration in Abu-Qir station in Spring. While El- Anfushi presented the highest concentration of $\mathrm{Zn}$ in Summer.
\end{abstract}


So it can be concluded that the concentrations of the studied metals associated with the soft tissues of Patella caerulea varied over the seasons and sampling sites. Summer and Autumn showed higher accumulation of trace metals in Parella tissues than the other seasons. There was a positive correlation between trace metals and levels of salinity and seasons, where the concentration of some trace metals increased in Summer with lower salinity as in El-Mex station. Finaly the soft tissues of $P$. cuerulea can be considered as a potential indicator, reflecting the environmental pollution by the present trace metals.

\section{INTRODUCTION}

Despite the low concentration of heavy metals in the surrounding medium, aquatic organisms take ; accumulate them up in their soft tissues to concentrations several folds higher than those of the ambient levels (Bryan, 1979 \& Rainbow, 1990). The usefulness of molluscs as sentinel organisms in metal biomonitoring studies is widely recognized (Rainbow, 1990, 1997; Langston and Spence, 1995; Brown and Depledge, 1998). Generally, metal concentrations in the soft tissues show greater variability due to seasonal weight changes (associated with physiological conditions and reproductive state). Due to this fact, some authors tried to avoid seasonal variations. When considering metal concentrations in the soft tissues of marine mollusks, they are correlated with shell weight, using metal/ shell weight indices ( Soto et al., 1995 \& 1997; Carvo et al., 2003 ). Lingard et al. (1992) and Cravo et al. (2003) have postulated that shells have important practical advantages over the soft tissues to monitor metal contamination of the aquatic environment to avoid seasonal variations and that shells integrate elemental concentrations over the life of the animal. Also uptake of heavy metals from solution by seaweed is influenced by factors such as light , temperature. salinity, season and presence of other pollutants in the surrounding water (Lobban and Harrison 1997). Rice et al. (1973) stated that, the order of metal toxicity to algae varies with the algal species and the experimental conditions. Due to the above reasons, the creatures may not accurately refiect metal concentration in water, beside the nature of the rocky intertidal habitat between the lowest and highest tidal levels. Organisms living in that area must be able to withstand periodic dessiccation. high temperature and light. low salinities and strong wave action (Nybakken,1982). However, insufficient 
information was available to comment further on the particular sensitivity of any species within the biotope.

This study aimed to examine the effect of the seasons on the concentrations of $\mathrm{Cd}, \mathrm{Co}, \mathrm{Cu} . \mathrm{Fu} . \mathrm{Pb}$ and $\mathrm{Zn}$ in water and Patella caerulea taken from three different stations and to detect which season is preferred to use this species as food by other animals and to establish the sensitivity of Patella caerulea to such pollutants within the biotope.

\section{MATERIALS AND METHODS}

\section{1- Study areas:}

Three stations (Abu-Qir, El-Anfushi and El-Mex), were selected to collect limpets. These stations represent different habitats on the Mediterranean coast. Rocky shores were visited seeking for Patella caerulea during Autumn 2001 to Summer 2002.

\section{2- Ecological investigation:}

Physico-chemical parameters of water, as water temperature $\left({ }^{\circ} \mathrm{C}\right)$, salinity $(\% \mathrm{o})$, Hydrogen ion concentration $(\mathrm{pH})$ and Dissolved Oxygen (DO) were determined seasonally. The latter was determined by using modified Winkler method (APHA. 1992).

\section{3- Determination of heavy metals:}

\section{3-1- Heavy metals in water:}

Three water samples from each station were analysed for $\mathrm{Cd} . \mathrm{Cu}$, $\mathrm{Co}, \mathrm{Fe}, \mathrm{Pb}$ and $\mathrm{Zn}$ concentrations. by using Atomic Absorption Spectrophotometer (AAS). Results obtained were expressed in (ppm).

\section{3-2- Heavy metals in limpet tissues:}

The heavy metals $\mathrm{Cd}, \mathrm{Cu}, \mathrm{Co}, \mathrm{Fe}, \mathrm{Pb}$ and $\mathrm{Zn}$ were measured in limpet tissues according to Dalziel \& Baker (1983) and Dybern (1983). The soft parts of three Patella caerulea individuals from each station were weighed, then $5 \mathrm{ml}$ of freshly prepared $1: 1 \mathrm{~V} / \mathrm{V}$ Hydrogen peroxide/conc. Nitric acid was added to each of them in glass tubes, that were then covered and placed aside for about an hour until the first reaction subsides, then the tubes were placed in sand bath on a hot plate at about $160^{\circ} \mathrm{C}$ for about 2 hours till complete digestion. The solutions were cooled and diluted to $25 \mathrm{ml}$ by distilled water. Heavy metals were determined in this solution by using AAS. The concentrations of heavy metals in the soft tissues were determined from the following equation: 
Element concentration in the sample $(\mu \mathrm{g} / \mathrm{gm}$ wet weight $)=(\mathrm{CXV}) \div \mathrm{W}$

Where: $\mathrm{C}=$ conc. of element in the solution.

$\mathrm{V}=$ volume of the solution.

$W=$ weight of the sample.

\section{4- Statistical analysis:}

The Statistical Package for Social Science (SPSS). Two-way ANOVA were employed to find stations, seasons and stations $X$ season differences. The t-test was used to confirm the differences of heavy metals concentrations between the seawater and limpet soft tissues at different stations and seasons.

\section{RESULTS}

\section{1- Physico-chemical parameters of water:}

\section{1-1- Temperature $\left({ }^{\circ} \mathrm{C}\right)$ :}

Surface water temperature recorded a marked seasonal fluctuation as shown in Table (1). It ranged from $18.467 \pm 0.033$ and $28.633 \pm 0.033^{\circ} \mathrm{C}$. The average minimum temperature value was recorded in Winter $\left(18.611 \pm 0.065^{\circ} \mathrm{C}\right)$ and the maximum one in Summer $\left(27.944 \pm 0.175^{\circ} \mathrm{C}\right)$. Regarding stations variations, minimum temperature was recorded at El-Anfushi $\left(22.942 \pm 0.990^{\circ} \mathrm{C}\right)$, while the maximum one was recorded at Abu-Qir $\left(23.525 \pm 1.122^{\circ} \mathrm{C}\right)$. The mean temperature for stations reached $23.233 \pm 0.580^{\circ} \mathrm{C}$.

\section{1-2- Hydrogen ion concentration $(\mathrm{pH})$ :}

The $\mathrm{pH}$ values at the studied stations ranged between $7.357 \pm 0.009$ and $8.067 \pm 0.024$, with an average value of $7.661 \pm 0.036$ (Table 2). Seasonal variations showed that, Autumn 2001 and Winter 2002 have the lowest $\mathrm{pH}$ values $(7.474 \pm 0.046$ and $7.499 \pm 0.011$ respectively), while Spring and Summer 2002 recorded the highest $\mathrm{pH}$ values $(7.842 \pm 0.032$ and $7.829 \pm 0.060$ respectively). Regarding to stations, El-Mex and El-Anfushi had the mininum values $(7.598 \pm 0.055$ and $7.627 \pm 0.057$ respectively) and Abu-Qir had the maximum value $(7.758 \pm 0.066)$. Analysis of variance for $\mathrm{pH}$ (ANOVA) showed that $\mathrm{pH}$ concentrations showed highly significant differences for both stations and seasons. 


\section{1-3- Salinity (\%o):}

As shown in Table (3), salinity varied between $24.400 \pm 0.058$ and $38.667 \pm 0.033 \%$ o. Seasonal variations showed that, Winter had the lowest value of salinity $(33.056 \pm 2.164 \%$ ) while Summer had the highest value $(33.956 \pm 2.103 \%$ o). Stations variations showed that, ElMex had the lowest value $(24.992 \pm 0.131 \% 0)$ and Abu-Qir had the highest value $(38.092 \pm 0.152 \% 0)$. The mean salinity for stations reached $33.544 \pm 1.025 \%$ o. Analysis of variance for salinity (ANOVA) revealed that highly significant differences for both stations and seasons.

\section{1-4- Dissolved Oxygen (DO):}

Dissolved oxygen throughout studied period at different stations ranged between $4.367 \pm 0.088$ and $7.933 \pm 0.033 \mathrm{mg} / \mathrm{l}$ with an average value $5.508 \pm 0.165 \mathrm{mg} / \mathrm{l}$ (Table 4). Seasonal variations of dissolved oxygen showed the lowest value in Summer $(4.689 \pm 0.155$ $\mathrm{mg} / \mathrm{l})$ and maximum value in Autumn $(6.478 \pm 0.376 \mathrm{mg} / \mathrm{l})$. Stations variations indicated minimum oxygen value at El-Mex $(4.842 \pm 0.122$ $\mathrm{mg} / \mathrm{l})$ and maximum value at Abu-Qir $\cdot(6.325 \pm 0.328 \mathrm{mg} / \mathrm{l})$. The analysis of variance in dissolved oxygen at the different stations and seasons, revealed highly significant differences for stations and seasons $(\mathrm{P} \leq 0.01)$.

\section{1-5- Biochemical Oxygen Demand (BOD):}

As shown in Table (5), the biochemical oxygen demand (BOD) ranged between $2.167 \pm 0.033$ and $5.833 \pm 0.033 \mathrm{mg} / \mathrm{l}$. The average BOD value being $3.686 \pm 0.204 \mathrm{mg} / \mathrm{l}$. The lowest mean value was recorded in Summer $(2.678 \pm 0.172 \mathrm{mg} / \mathrm{l})$, while the maximum BOD value was recorded in Autumn $(4.356 \pm 0.383 \mathrm{mg} / \mathrm{l})$. Variation of BOD values at different stations revealed the lowest value at El-Mex $(2.692 \pm 0.126 \mathrm{mg} / \mathrm{l})$ and the highest value at Abu-Qir $(5.025 \pm 0.307$ $\mathrm{mg} / \mathrm{l})$. The analysis of variance in BOD at different stations and seasons revealed that the $\mathrm{BOD}$ concentrations recorded highly significant differences for both stations and seasons $(\mathrm{P} \leq 0.01)$. 


\section{2-Trace metals concentrations:}

\section{2-1- Cadmium (Cd) :}

\section{2-1-A : In sea water}

The concentration of cadmium in sea water surface of the studied stations (Table 6 and Fig. 1) recorded that the minimum values in Winter and Spring $2002(0.061 \pm 0.007$ and $0.066 \pm 0.007 \mu \mathrm{g} / \mathrm{ml}$ respectively) and the maximum values in Autumn 2001 and Summer $2002(0.081 \pm 0.009$ and $0.078 \pm 0.009 \mu \mathrm{g} / \mathrm{ml}$ respectively). Stations variations showed that, Abu-Qir and El-Anfushi had the lowest values $(0.058 \pm 0.003$ and $0.056 \pm 0.003 \mu \mathrm{g} / \mathrm{ml}$ respectively) and El-Mex had the highest one $(0.100 \pm 0.005 \mu \mathrm{g} / \mathrm{ml})$. The average value of cadmium concentration reached $0.071 \pm 0.004 \mu \mathrm{g} / \mathrm{ml}$. Analysis of variance for $\mathrm{Cd}$ concentration in water. Analysis of variance (ANOVA), revealed highly significant differences for stations and seasons. $P \leq 0.01$, while non-significant for stations $\mathrm{X}$ seasons, $\mathrm{P} \geq 0.05$.

\section{2-1-B : In Patella tissues}

The total mean $\mathrm{Cd}$ concentration in Patella caerulea reached $0.671 \pm 0.021 \mu \mathrm{g} / \mathrm{gm}$ (Table 7 and Fig. 1), which recorded the minimum value in Winter $2002(0.524 \pm 0.025 \mu \mathrm{g} / \mathrm{gm})$ and maximum value in Autumn 2001, Spring and Summer $2002(0.748 \pm 0.029$. $0.691 \pm 0.022$ and $0.720 \pm 0.042 \mu \mathrm{g} / \mathrm{gm}$ respectively). Stations variations showed that. Abu-Qir and El-Anfushi had the lowest values $(0.630 \pm 0.028$ and $0.628 \pm 0.029 \mu \mathrm{g} / \mathrm{gm}$ respectively) while the highest value was recorded at El-Mex $(0.754 \pm 0.039 \mu \mathrm{g} / \mathrm{gm})$. Stations and seasons revealed highly significant differences, $(\mathrm{P} \leq 0.01)$, while stations $X$ seasons revealed non-significant differences for $\mathrm{Cd}$ concentrations, $(P \geq 0.05)$.

\section{2-2-Cobalt (Co):}

\section{2-2-A : In sea water}

The minimum Co concentration was recorded in Autumn 2001 $(0.058+0.003 \mu \mathrm{g} / \mathrm{ml})$, while the maximum value was recorded in Winter $2002(0.077+0.005 \mu \mathrm{g} / \mathrm{ml})$ (Table 8 and Fig. 2). Stations variations revealed a lower Co concentration at El-Mex $(0.058+0.004$ $\mu \mathrm{g} / \mathrm{ml})$, while the higher was at El-Anfushi $(0.073+0.003 \mu \mathrm{g} / \mathrm{ml})$. The mean stations value of Co reached $0.067+0.002 \mu \mathrm{g} / \mathrm{ml}$. Analysis of variance in $\mathrm{Co}$ concentrations at different stations and seasons, revealed highly significant differences $(\mathrm{P}<0.01)$ for stations 


\section{2-1-B : In Patella tissues}

The total mean $\mathrm{Cd}$ concentration in Patella caerulea reached $0.671 \pm 0.021 \mu \mathrm{g} / \mathrm{gm}$ (Table 7 and Fig. 1). which recorded the minimum value in Winter $2002(0.524 \pm 0.025 \mu \mathrm{g} / \mathrm{gm})$ and maximum value in Autumn 2001. Spring and Summer $2002(0.748 \pm 0.029$. $0.69 \mathrm{I} \pm 0.022$ and $0.720 \pm 0.042 \mu \mathrm{g} / \mathrm{gm}$ respectively). Stations variations showed that, Abu-Qir and El-Anfushi had the lowest values $(0.630 \pm 0.028$ and $0.628 \pm 0.029 \mu \mathrm{g} / \mathrm{gm}$ respectively) while the highest value was recorded at El-Mex $(0.754 \pm 0.039 \mu \mathrm{g} / \mathrm{gm})$. Stations and seasons revealed highly significant differences. $(P \leq 0.01)$. white stations $\mathrm{X}$ seasons revealed non-significant differences for $\mathrm{Cd}$ concentrations. $(P \geq 0.05)$.

\section{2-2-Cobalt (Co):}

\section{2-2-A : In sea water}

The minimum Co concentration was recorded in Autumn 2001 $(0.058 \pm 0.003 \mu \mathrm{g} / \mathrm{ml})$, while the maximum value was recorded in Winter $2002(0.077 \pm 0.005 \mu \mathrm{g} / \mathrm{ml})$ (Table 8 and Fig. 2). Stations variations revealed a lower Co concentration at El-Mex $(0.058 \pm 0.004$ $\mu \mathrm{g} / \mathrm{ml})$, while the higher was at El-Anfushi $(0.073 \pm 0.003 \mu \mathrm{g} / \mathrm{ml})$. The mean stations value of Co reached $0.067 \pm 0.002 \mu \mathrm{g} / \mathrm{ml}$. Analysis of variance in $\mathrm{Co}$ concentrations at different stations and seasons, revealed highly significant differences $(P \leq 0.01)$ for stations and seasons and non-significant differences for stations $X$ seasons $(\mathrm{P} \geq 0.05)$.

\section{2-2-B : In Patella tissues:}

The minimum Cobalt concentrations of Patella tissues was at Abu-Qir $(0.737 \pm 0.069 \mu \mathrm{g} / \mathrm{gm})$ and the maximum value at El-Anfushi $(1.321 \pm 0.201 \mu \mathrm{g} / \mathrm{gm})$, but no marked differences between seasons. (Table 9 and Fig. 2). The mean value for stations reached to $0.985 \pm 0.084 \mu \mathrm{g} / \mathrm{gm}$. Analysis of variance (ANOVA) revealed significant differences for stations, $(\mathrm{P} \leq 0.05)$ and non-significant for seasons or stations $X$ seasons, $(P \geq 0.05)$. 


\section{2-3- Copper (Cu):}

\section{2-3-A: In sea water:}

' he concentrations of copper in the three stations (Table 10 and Fig. ' reached the minimum value in Autumn $(0.072 \pm 0.002$ $\mu \mathrm{g} / \mathrm{ml}$ ) al. maximum value in Summer $(0.088 \pm 0.002 \mu \mathrm{g} / \mathrm{ml})$. AbuQir had live lowest value of $\mathrm{Cu}$ concentration $(0.076 \pm 0.003 \mu \mathrm{g} / \mathrm{ml})$, while El-Anfushi and El-Mex had the highest values $(0.083 \pm 0.003$ and $0.083 \pm 0.002 \mu \mathrm{g} / \mathrm{ml}$ respectively). The mean $\mathrm{Cu}$ concentrations for stations reached $0.081 \pm 0.002 \mu \mathrm{g} / \mathrm{ml}$. Analysis of variance (ANOVA) for $\mathrm{Cu}$ concentration revealed significant differences for stations, and seasons $(P \leq 0.01, P \leq 0.05)$ respectively, while stations $X$ seasons revealed non-significant differences $(P \geq 0.05)$.

\section{2-3-B: In Patella tissues.}

Copper concentration in whole soft tissues of Patella caerulea revealed no marked differences between seasons (Table 11 and Fig. $3)$. The minimum values of $\mathrm{Cu}$ concentration were recorded at AbuQir and El-Anfushi $(4.815 \pm 0.308$ and $3.603 \pm 0.275 \mu \mathrm{g} / \mathrm{gm}$ respectively) while the maximum value at El-Mex station $(8.577 \pm 1.159 \mu \mathrm{g} / \mathrm{gm})$. The total mean for stations being $5.665 \pm 0.535 \mu \mathrm{g} / \mathrm{gm}$. ANOVA revealed highly significant differences for stations, $(\mathrm{P} \leq 0.0) 1$ and non-significant for seasons, $(P \geq 0.05)$ and Stations $X$ seasons.

\section{2-4-Iron (Fe):}

\section{2-4-A : In sea water}

Fe concentrations ranged between $0.024 \pm 0.011$ and $0.165 \pm 0.022$ $\mathrm{\mu g} / \mathrm{ml}$ and its total mean for stations reached $0.065 \pm 0.006 \mu \mathrm{g} / \mathrm{ml}$ (Table 12 and Fig. 4). Autumn 2001 and Winter 2002 recorded the lowest value of $\mathrm{Fe}$ concentrations $(0.051 \pm 0.007$ and $0.037 \pm 0.006$ $\mu \mathrm{g} / \mathrm{ml}$ respectively) and Spring 2002 recorded the highest value $(0.102 \pm 0.017 \mu \mathrm{g} / \mathrm{ml})$. Stations variations indicated minimum values of Fe at El-Anfushi and El-Mex $(0.044 \pm 0.005$ and $0.056 \pm 0.006 \mu \mathrm{g} / \mathrm{ml}$ respectively) and maximum value at Abu-Qir $(0.097 \pm 0.014 \mu \mathrm{g} / \mathrm{ml})$. Analysis of variance (ANOVA) revealed highly significant differences for stations. seasons and stations $X$ seasons, $(P \leq 0.01)$. 
Lead concentrations in whole tissues of Patella caerulea (Table 15 and Fig. 5), ranged between $0.532 \pm 0.078$ and $3.553 \pm 0.122 \mu \mathrm{g} / \mathrm{gm}$ with an average of $1.738 \pm 0.157 \mu \mathrm{g} / \mathrm{gm}$. The minimum $\mathrm{Pb}$ concentration were recorded in Spring and Summer 2002 $(1.139 \pm 0.196$ and $1.232 \pm 0.212 \mu \mathrm{g} / \mathrm{gm}$ respectively) while the nlaximum value was recorded in Autumn 200! $(2.725 \pm 0.256 \mu \mathrm{g} / \mathrm{gm})$. Stations variations revealed the lowest value at Abu-Qir $(0.936 \pm 0.161$ $\mu \mathrm{g} / \mathrm{gm})$ and highest value at El-Mex $(2.555 \pm 0.213 \mathrm{tg} / \mathrm{gm})$. ANOVA recorded highly significant differences in $\mathrm{Pb}$ concentration for stations. seasons and stations $X$ seasons $(P \leq 0.01)$.

2-5- Lead (Pb):

2-5-A: In sea water.

Winter, Spring and Summer 2002 showed the minimum values of $\mathrm{Pb}$ concentrations $(0.425 \pm 0.109,0.308 \pm 0.087$ and $0.345 \pm 0.105 \mu \mathrm{g} / \mathrm{ml}$ respectively) while Autumn $200 \mathrm{l}$ had the maximum value $(0.653 \pm 0.178 \mu \mathrm{g} / \mathrm{ml}$ ) (Table 14 and Fig. 5). A bu-Qir and El-Anfushi had the lowest $\mathrm{Pb}$ concentrations $(0.165 \neq 0.023$ and $0.293 \pm 0.077$ $\mu \mathrm{g} / \mathrm{ml}$ respectively) and El-Mex had the higher value $(0.840 \pm 0.094$ $\mu \mathrm{g} / \mathrm{ml})$. The mean $\mathrm{Pb}$ concentrations of all stations reached $0.433 \pm 0.064 \mu \mathrm{g} / \mathrm{ml}$. ANOVA revealed highly significant differences for stations and seasons, $(\mathrm{P} \leq 0.01)$ and non-significant differences for stations $X$ seasons, $(P \geq 0.05)$.

\section{2-5-B: In Patella tissues:}

Lead concentrations in whole tissues of Patella caerulea (Table 15 and Fig. 5). ranged between $0.532 \pm 0.078$ and $3.553 \pm 0.122 \mu \mathrm{g} / \mathrm{gm}$ with an average of $1.738 \pm 0.157 \mu \mathrm{g} / \mathrm{gm}$. The minimum $\mathrm{Pb}$ concentration were recorded in Spring and Summer 2002 $(1.139 \pm 0.196$ and $1.232 \pm 0.212 \mu \mathrm{g} / \mathrm{gm}$ respectively) while the maximum value was recorded in Autumn $2001(2.725 \pm 0.256 \mu \mathrm{g} / \mathrm{gm})$. Stations variations revealed the lowest value at Abu-Qir $(0.936 \pm 0.161$ $\mu \mathrm{g} / \mathrm{gm})$ and highest value at El-Mex $(2.555 \pm 0.213 \mu \mathrm{g} / \mathrm{gm})$. ANOVA recorded highly significant differences in $\mathrm{Pb}$ concentration for stations, seasons and stations $X$ seasons $(P \leq 0.01)$.

\section{2-6- Zinc (Zn):}

\section{2-6-A: In sea water}

The minimum concentration of $\mathrm{Zn}$ was recorded in Winter $(0.067+0.003 \mu \mathrm{g} / \mathrm{ml})$ while the maximum was recorded in Summer $(0.123+0.012 \mu \mathrm{g} / \mathrm{ml}$ ) (Table 16 and Fig. 6). Stations variations 
showed that, El-Mex had the lowest $\mathrm{Zn}$ concentration $(0.077+0.005$ $\mu \mathrm{g} / \mathrm{ml})$ while the highest value at El-Anfushi $(0.109+0.011 \mu \mathrm{g} / \mathrm{ml})$. The average $\mathrm{Zn}$ concentrations for stations being $0.095+0.005 \mu \mathrm{g} / \mathrm{ml}$. Analysis of variance (ANOVA), revealed highly significant differences for stations and seasons $(P<0.01)$ and non-significant differences for stations $X$ seasons $(P>0.05)$.

\section{2-6-B: In Patella tissues}

The minimum concentration of $\mathrm{Zn}$ was recorded in Winter $(0.067 \pm 0.003 \mu \mathrm{g} / \mathrm{ml})$ while the maximum was recorded in Summer $(0.123 \pm 0.012 \mu \mathrm{g} / \mathrm{ml}$ ) ( Table 17 and Fig. 6). Stations variations showed that, El-Mex had the lowest value of $\mathrm{Zn}$ concentration $(0.077 \pm 0.005$ $\mu \mathrm{g} / \mathrm{mi})$, while the highest value was at El-Anfushi $(0.109 \pm 0.011 \mu \mathrm{g} / \mathrm{mi})$. The average $\mathrm{Zn}$ concentrations for stations being $0.095 \pm 0.005 \mu \mathrm{g} / \mathrm{ml}$. Analysis of variance (ANOVA), revealed highly significant differences for stations and seasons $(P \leq 0.01)$ and non-significant differences for stations $X$ seasons $(P \geq 0.05)$.

\section{DISCUSSION}

The present data indicated that the concentrations of trace metals associated with soft tissues of Patella caerulea varied over the seasons and sampling sites. The discussion of this matter needs first to know the physico-chemical parameters of water which are controlled by the seasons, then the quality of sites, (polluted or not). and the type of pollution. For example the $\mathrm{Pb}$ concentration in soft tissues of Palella caerulea collected from Abu-Qir in Autumn recorded nearly three fold its concentration in Summer. Also the concentration of $\mathrm{Pb}$ in El-Mex station was nearly three fold its concentration in Abu-Qir. So, comparison between the published works are insufficient, because many of them have deternined the accumulated trace metals related to nature of sites and neglected the seasons affecting those sites ( Bargagli et al., 1985; Ramelow, 1985; El-Rayis and Ezzat. 1986; Puel et al., 1987; El-Gamal. 1988; Rifaat, et al., 1997: Farag. et al., 2000 ; Cravo et al., 2003).

The physico-chemical conditions of the rocky shore intertidal zones where Patella occurs are extreme. Such habitats seasonally are subject to periodic desiccation, high temperature and light, low salinities and strong wave action (Nybakken, 1982). So it is difficult 
to put fixed record of trace metals with the seasonal changes of temperature, oxygen partial pressure, salinity and the behavior of animals towards these changes.

The present results showed that the surface water temperature ranged between $18.467 \pm 0.033$ and $28.63 \pm 0.033^{\circ} \mathrm{C}$. within difterent seasons. Summer recorded the highest concentration of some metals and the lowest in others. The lowest concentrations of $\mathrm{Fe}, \mathrm{Zn}$ and $\mathrm{Cd}$ were recorded in winter, while Co was high. Autumn recorded the highest concentration of $\mathrm{Cd}$ and $\mathrm{Pb}$ while the highest $\mathrm{Fe}$ was recorded in Spring. Moreover. each season behaves differently towards the concentration of metals. Summer and Autumn recorded the highest concentrations of trace metals than Winter and Spring. that may be due to the effect of temperature and wind on the solubility of these metals.

Salinity values ranged between $24.4 \pm 0.058$ and $38.667 \pm 0.033 \%$. where the lowest value was recorded at El-Mex station, which may be due to the influence of the major outlet from Umum drain, carrying is mixed agricultural drainage water outflow from Lake Mariut with its industrial wastes. It enriches the bay with detrital material and nutrient salts as well as pesticides and heavy metals ( Halim, 1983 and Atta, 1991). The low salinities play a big role in the accumulation of the trace metals in the soft tissues of patella. For example. $\mathrm{Cu}$ concentration in El-Anfushi and El-Mex were $0.073(\mu \mathrm{g} / \mathrm{mi})$ while its accumulation in the soft tissues reached $2.42 \pm 0.24$ and $6.97 \pm 0.64$ $(\mu \mathrm{g} / \mathrm{gm})$ respectivily. Lower salinity during Summer gave the highest ratio of $\mathrm{Cu}$ accumulation than the other seasons $(9.989 \pm 0.83 \mu \mathrm{g} / \mathrm{gm})$. The same results were obtained with other stations, where the salinity. temperature and the accumulation of metals were correlated. This is applied also for $\mathrm{Zn}$ and $\mathrm{Cd}$, while for $\mathrm{Pb}$ and $\mathrm{Co}$, lower temperature with lower salinities gave the highest accumulation.

Seasonal fluctuation in $\mathrm{pH}$ values in the studied sites were limited and ranged between $7.357 \pm 0.009$ and $8.067 \pm 0.024$. Spring recorded higher $\mathrm{pH}$ value than the rest of seasons, to growth of hydrophytes and phytoplankton (Abdel- Baky \& El-Gobashi, 1991). No changes were recorded for $\mathrm{pH}$ on the ratio of trace metals accumulation.

The dissolved oxygen depends mainly on the physico- chemical parametrs. Herbst \& Dana, (1980) reported that, when the temperature of a salt solution increases, the solubility of oxygen 
decreases. This coincides with the present data, where Summer recorded the lowest value of dissolved oxygen, while Autumn recorded the highest one.

The dissolved oxygen reflects the pattern of biochemical oxygen demand fluctuation that followed more or less the seasonal and site variations of dissolved oxygen value (Sowyer and McCarty, 1978). So the decrease in dissolved oxygen during summer at El- Mex station was followed by decreasing in biochemical oxygen demand at the same season and station. The lowest $\mathrm{O}_{2}$ value was recorded in ElMex which recorded the highest value of pollution. Moreover dissolved oxygen plays an indirect role in the accumulation of trace metals in soft parts of Patella.

El-Mex contributed the highest concentration of $\mathrm{Cu}, \mathrm{Pb}$ and $\mathrm{Cd}$ in both water and soft tissues of Patella caerulea than those taken from El- Anfushi and Abu- Qir. From this comparison, it is tempting to conclude that $\mathrm{Cu}, \mathrm{Pb}$ and $\mathrm{Cd}$ concentrations associated with $\mathrm{E}$ !- Mex limpets are a direct reflection of the availability of metals by the impact of untreated industrial, agricultural and sewage contamination. According to Abdel-Moati, (1991), El-Mex station receives annually two tons of $\mathrm{Pb}$ through the effluent from ethyl lead unit of Alexandria Petroleum Company. The high concentration of metals were recorded in Summer and Autumn, indicated that. the temperature and wind play a role in the enrichement of these metals. Abu-Qir station at the most eastern part of Alexandria coast line, recives a lot of domestic waste water but no industrial effluents (Atta, 1991), so it was the lowest station in trace metals pollution but only recorded highest concentration of Fe. Many data recorded high concentration of iron in the soft tissues of Patella caerulea as other patella species ( Bargagli et al., 1985; Ramelow, 1985; El- Rayis and Ezzat, 1986; Puel et cil.. 1987 and Cravo ef al.. 2003), which may be ascribed to the fact that iron is a constituent of goethite $(\mathrm{J}-\mathrm{FeOOH})$ present in the radula of Patellidae (Runham et al., 1969; Fish and Fish, 1989). El- Anfushi station recorded higher values of $\mathrm{Fe}, \mathrm{Co}$ and $\mathrm{Pb}$ which may be due to repairing of Qaitbay fort during the study period.

A comparison of the present results as mean of all seasons. with the previous studies from a wide range of geographical locations and different environmental regimes is presented in Table(18). The comparison showed that, the concentration of any trace metals 
associated with the soft tissues vary over a wide range. In all Patella species, there is a general tendency for iorn and zinc to be preferably incorporated into the soft tissues as found in investigated species and other marine gastropods (Puel et al., 1987; Depledge et al., 1994 ; de Wolf et al., 2001). However, metal concentrations in soft tissues of Patella caerulea affected by sewage discharges when comparable to those of other Patella sp.taken from sites influenced by industrial discharges.

\section{REFERENCES}

Abdel-Baky, T. and El-Ghobashy, A. (1991). Seasonal variation of mineral contents in four species of cichlid fishes from lake Manzalah, Egypt. J. Egypt. Ger. Soc. Zool.. 6(A): 283-296.

Abdel-Moati, M. A. R. (1991). Biochemical and physiological responses of Mytilus edulis to $\mathrm{Hg}$ and $\mathrm{Pb}$ in the coastal waters of Alexandria region. FAO/UNEP/IOC. Workshop on the Biological effects of Pollutants on Marine Organisms. Athens (Greece): 61-72.

APHA, (1992). Standard Methods for the Examination of Water and Waste Water. Washington, $18^{\text {th }}$ Ed. DC.

Atta, M. M. (1991). Rocky shore fauna of Mediterranean coastline of Alexandria. 1. Egypt. Ger. Soc. Zool., 5:211-224.

Bargagli, R. ; Baldi. F. and Leonzio, C. (1985). Trace metal assessment in sediments, molluscs and reed leaves in the bay of Follonica (Italy). Mar Environ Res, 16: 281-300.

Brown, M. T. and Depledge, M. H. (1998). Determinants of trace metal concentrations in marine organisms. In: Langston W, Bebianno M.J, editors. Metal metabolism in aquatic environments. London: Chapman \& Hall. p. 185-217.

Cravo, A. ; Bebiano, M. J. and Foster, P. (2003). Partitioning of trace metals between soft tissues and shells of Parella cispera. Furionn int (in nram) 
Dalziel, J. and Baker, C. (1983). Analytical methods for measuring metals by atomic absorption spectrometry. FAO Fish. Technical paper, 212:14-21.

Depledge, M. H. ; Weeks, J. M. and Bjerregaard, P. (1994). Heavy metals. In Calow P, editor. Handbook of ecotoxicology, Vol. 2. Oxford: Blackwell; pp. 79-105.

De Wolf, H. ; Ulomi, S. A. ; Backeljau, T. And Blust, R. (2001). Heavy metal levels in the sediments of four Dar es Salaam mangroves. Accumulationin, and effect on the morphology of the preiwinkle. Litroraria scabra. Environ Int: 26(4):2439

Dybern, B. (1983). Field sampling and preparation of subsamples of aquatic organisms for analysis of metals and organochlorines. FAO, Fisher Tech. Paper, 212:1-13.

El-Gamal, M. M. T. (1988). "Studies on marine edible molluscs of Egypt". M.Sc. Thesis, Fac. Sci., Tanta Univ., Egypt.

El-Rayis, O. A. and Ezzat, A. A. (1986). Bioaccumulation of some heavy metals in coastal marine animals in the vicinity of Alexandria: . Surveying. FAO Fish Rep. 334: 67-72.

Farag, E. A. ; Dekinesh, S. I. and El-Odessy. H. M. (2000). Trace elements accumulation in soft parts of six edible bivalve molluscs inhabiting Alexandria coast. Egypt. J. Egypt. Ger. Soc. Zool., 3/(D): 27-36.

Fish, J. D. and Fish. S. (1989). A student's guide to the seashore. London: Unwin Hyman; 473pp.

Halim, Y. (1983). Mid Term. Technical report aquatic environmental pollution project EGY/73/058, University of Alexandria, Research Center Alexandria. 
Herbst, D. B. and Dana, G. L. (1980). Environmental physiology of salt tolerance in the alkaline salt lake population of Artcmic from Mono Lake, California, U.S.A.. In, The Brin Shrimp Ariemia. Volume 2. Physiology, Biochennistry, Molecular Biology. Wetteren, Belgium, Univera, pp. 157-167.

Langston, W. J. and Spence, K. (1995). Biological factors involved in metal concentrations observed in aquatic organisms. In: Tessier A, Tumer DR, editors. Metal speciation and bioavailability in aquatic systems. New York: Wiley: pp. 407-78.

Lingard, S. M. ; Evans, R. D. and Bourgoin, B. P. (1992). Method for the estimation of organic-bound and crystal-bound metal concentrations in bivalves shells. Bull Environ Contam Toxicol., 48:179-84.

Lobban, C. S. and Harrison, P. J. (1997). Seaweed ecology and physiology. Cambridge: Cambridge University Press.

Nybakken, J. W. (1982). Marine biology: An Ecological Approach. New York, NY. Harper \& Row.

Puel, D. ; Zsurger, N. and Breittmeyer, JPh. (1987). Statistical assessment of a sampling pattern for evaluation of changes in mercury and zinc concentrations in Patella caerulea. Bull Environ Contam Toxicol.. 38:700-6.

Rainbow. P. S. (1990). Heavy metal levels in marine invertebrates. In heavy metals in the marine environment (ed. R.W. Furness and P.S. Rainbow), pp.67-79. Boca Raton, Florida: CRC Press.

Răinbow, P. S. (1997). Trace metal accumulation in marine invertebrates: marine biology or marine chemistry. I. Mar. Biol. Ass. U.K., 77:195-210. 
Ramelow. G. J. (1985). Astudy of heavy metals in limpets (Patella sp.) collected along a section of the southeastern Turkish Mediterranean coast. Mar Environ Res; 16:243-53.

Rice, H. ; Leighty, D. A. and McLeod, G. C. (1973). The effects of some trace metals on marine phytoplankton. CRC Critical Review in Microbiology. 3:27-49.

Rifaat. A. E. : El-Mamoney, M. H. and Draz. S. E. (1997). The organic matter, iron. copper, manganese. zinc and cadmium in 1982 and 1995 in El'Mex Bay sediments, Alexandria. Egypt.

Runham, N. W. ; Thomton, P. R. : Saw, D. A. and Wayte. R. C. (1969). The mineralization and hardness of the radular teeth of the limpet Patella valgata L. Z Zell-forsch, 99:608-26.

Sawyer, C. N. and McCarty, P. L. (1978). Chemistry for Environmental Engineering, 3 rd Eddition. Mc Graw-Hill Book company, NY. NY. $532 \mathrm{pp}$.

Soto, M. ; Kortabitarte. M. and Marigomez. I. (1995). Bioavailable heavy metals in estuarine waters as assessed by metal/shellweight indices in sentinel mussels Mytilus galloprovincialis. Mar Ecol, Prog Ser, /25(1-3):127-31.

Soto, M. ; Ireland, M. P. and Marigomez. I. (1997). The contribution of metal/shell-weight index in target tissues to metal body burden in sentinel marine molluscs: 2. Mytilus galloprovincialis. Sci Total Environ., $189(2): 149-60$. 
Table (1): Seasonal variations in temperature $\left({ }^{\circ} \mathrm{C}\right)$ of sea water surface at three stations of A lexandria during Autumn 2001 to Summer 2002. (a-k, sequence of temperature values and $A-C$, sequence of total means at different stations and seasons; $M \pm S E$, mean \pm standard error of 3 determinations).

\begin{tabular}{|c|c|c|c|c|}
\hline Station & Abu-Qir & El-Anfushi & EI-Mex & $M \pm S E$ \\
\hline Autumn & $24.867 \pm 0.033$ & $24.033 \pm 0.033$ & $\begin{array}{c}24.367 \pm 0.033 \\
\mathrm{e}\end{array}$ & $24.422 \pm 0.122$ \\
\hline Winter & $\begin{array}{c}18.467 \pm 0.033 \\
k\end{array}$ & $\begin{array}{c}18.500 \pm 0.000 \\
k\end{array}$ & $18.867 \pm 0.033$ & $\frac{18.611 \pm 0.065}{D}$ \\
\hline Spring & $\begin{array}{c}22.133 \pm 0.067 \\
3\end{array}$ & $21.733 \pm 0.033$ & $22.000 \pm 0.000$ & $21.956 \pm 0.063$ \\
\hline Summer & $\begin{array}{c}28.633 \pm 0.033 \\
a\end{array}$ & $27.500 \pm 0.000$ & $\begin{array}{c}27.700 \pm 0.000 \\
b\end{array}$ & $\begin{array}{c}27.944 \pm 0.175 \\
\mathrm{~A}\end{array}$ \\
\hline$M \pm S E$ & $\frac{23.525 \pm 1.122}{A}$ & $22.942 \pm 0.990$ & $\begin{array}{c}23.233 \pm 0.975 \\
\mathrm{~B}\end{array}$ & $23.233 \pm 0.580$ \\
\hline
\end{tabular}

Table (2): Seasonal variations in hydrogen ion concentration $(\mathrm{pH})$ of sea water surface at three stations of Alexandria during Autumn 2001 to Summer 2002. (a-e, sequence of pH concentrations and $A-C$, sequence of total means at different stations and seasons: $M \pm S E$. mean \pm standard error of 3 determinations).

\begin{tabular}{|c|c|c|c|c|}
\hline $\begin{array}{l}\text { Station } \\
\text { Season }\end{array}$ & Abu-Qir & El-Anfushi & El-Mex & $\mathrm{M} \pm \mathrm{SE}$ \\
\hline Autumn & $\begin{array}{c}7.653 \pm 0.009 \\
\mathrm{c}\end{array}$ & $7.413 \pm 0.012$ & $\begin{array}{c}7.357 \pm 0.009 \\
\mathrm{e}\end{array}$ & $7.47 \frac{ \pm}{\mathrm{B}}$ \\
\hline Winter & $7.497 \pm 0.003$ & $7.500 \pm 0.006$ & $7.500 \pm \frac{0}{d} .036$ & $\frac{7.499 \div 0.011}{\mathrm{~B}}$ \\
\hline Spring & $7.813 \pm 0.088$ & $\begin{array}{c}7.887 \pm 0.055 \\
b\end{array}$ & $7.827 \pm 0.003$ & $7.842 \pm 0.032$ \\
\hline Summer & $\begin{array}{c}8.067 \pm 0.024 \\
a\end{array}$ & $7.710 \pm 0.006$ & $\underset{c}{7.710 \pm 0.006}$ & $\frac{7.829 \pm 0.060}{\mathrm{~A}}$ \\
\hline$M \pm S E$ & $\begin{array}{c}7.758 \pm 0.066 \\
A\end{array}$ & $7.627+0.057$ & $7.598 \pm 0.055$ & $7.661 \pm 0.036$ \\
\hline
\end{tabular}


Table (3): Seasonal variations in salinity (\%o) of sea water surface at three stations in Alexandria during Autumn 2001 to Summer 2002. (a-j, sequence of salinity values and A-C, sequence of total means at different stations and seasons; $M \pm S E$. mean \pm standard error of 3 deterninationsis).

\begin{tabular}{|c|c|c|c|c|}
\hline Season & Abu-Qir & El-Anfushi & El-Mex & $\mathrm{M} \pm \mathrm{SE}$ \\
\hline Autumn & $37.900 \pm 0.058$ & $37.200 \pm 0.058$ & $24.833 \pm 0.033$ & $33.311=2.122$ \\
\hline Winter & $37.367 \pm 0.033$ & $37.400 \pm 0.058$ & $24.400 \div 0.058$ & $\begin{array}{c}33.056=? .104 \\
D\end{array}$ \\
\hline Spring & $\begin{array}{c}38.433 \pm 0.033 \\
b\end{array}$ & $\begin{array}{c}37.967=0.120 \\
c\end{array}$ & $25.167 \pm 0.033$ & $\begin{array}{c}33.856-2.174 \\
B\end{array}$ \\
\hline Summer & $\begin{array}{c}38.667 \pm 0.033 \\
a\end{array}$ & $37.633 \pm 0.033$ & $\begin{array}{c}25.567 \pm 0.033 \\
\mathrm{~g}\end{array}$ & $33.956=2.103$ \\
\hline
\end{tabular}

Table (4): Seasonal variations in dissolved oxygen concentration ( $\mathrm{mg} / \mathrm{l})$ of sea water surface at three stations in Alexandria during Autumn 2001 to Summer 2002. (a-lh, sequence of DO concentrations and A-C. sequence of total means at different stations and seasons: $M \pm S E$, mean \pm standard error of 3 determinations).

\begin{tabular}{|c|c|c|c|c|}
\hline Season Station & Abu-Qir & El-Anfushì & EI-Mex & $\mathrm{M} \pm \mathrm{SE}$ \\
\hline Autumn & $\begin{array}{c}7.933 \pm 0.033 \\
a\end{array}$ & $\frac{0.067 \pm 0.033}{c}$ & $\begin{array}{c}5.433+0.033 \\
\mathrm{de}\end{array}$ & $6.478+0.376$ \\
\hline Winter & $\begin{array}{c}5.433 \pm 0.033 \\
\text { de }\end{array}$ & $5.333 \pm 0.033$ & $\begin{array}{c}4.633 \pm 0.033 \\
\mathrm{~g}\end{array}$ & $5.133 \frac{1 \pm 0.127}{C}$ \\
\hline Spring & $\frac{6.700 \pm 0.100}{b}$ & $5.567 \pm 0.033$ & $4.933+0.033$ & $\frac{5.733 \pm 0.260}{B}$ \\
\hline Summer & $\frac{5.233 \pm 0.033}{\mathrm{e}}$ & $\begin{array}{c}4.467 \pm 0.233 \\
\mathrm{gh}\end{array}$ & $\begin{array}{c}4.367 \pm 0.088 \\
h\end{array}$ & $\frac{4.689 \pm 0.155}{D}$ \\
\hline $\mathrm{M} \pm \mathrm{SE}$ & $6.325+0.328$ & $\frac{5.358 \pm 0.182}{B}$ & $4.842+0.122$ & $5.508 \pm 0.165$ \\
\hline
\end{tabular}


Table (5): Seasonal variations in biochemical oxygen demand concentration (mg/l) of sea water surface at three stations in Alexandria during Autumn 2001 to Summer 2002. (a-i, sequence of $B O D$ concentrations and A-C. sequence of total means at different stations and seasons; $M \pm S E$. mean \pm standard error of 3 determinations).

\begin{tabular}{|c|c|c|c|c|}
\hline $\begin{array}{l}\text { Station } \\
\text { Season }\end{array}$ & Abu-Qir & El-Anfushi & EI-Mex & $M \pm S E$ \\
\hline Autumn & $\frac{5.833 \pm 0.033}{a}$ & $3.967 \pm 0.033$ & $3.267+0.033$ & $4.356 \pm 0.0 .383$ \\
\hline Winter & $\begin{array}{c}5.367 \pm 0.067 \\
c\end{array}$ & $3.267 \pm 0.033$ & $2.467 \frac{0.033}{h}$ & $3.700+0.433$ \\
\hline Spring & $5.600 \pm 0.000$ & $\frac{3.567 \pm 0.033}{\mathrm{e}}$ & $\begin{array}{c}2.867 \pm 0.033 \\
\mathrm{~g}\end{array}$ & $\frac{4.011+0.410}{B}$ \\
\hline Summer & $3.300 \pm 0.153$ & $\frac{2.567 \pm 0.033}{h}$ & $2.167+0.033$ & $\begin{array}{c}2.678 \pm 0.172 \\
D\end{array}$ \\
\hline $\mathrm{M} \pm \mathrm{SE}$ & $5.025 \pm 0.307$ & $\frac{3.342+0.155}{B}$ & $\frac{2.692 \pm 0.126}{C}$ & $3.686 \pm 0.204$ \\
\hline
\end{tabular}

Table (6): Seasonal variations in Cd concentration $(\mu \mathrm{g} / \mathrm{ml})$ of sea water surface at three stations in Alexandria during Autumn 2001 to Summer 2002. ( $A-C$, sequence of total $C d$ concentrations means at different stations and seasons; $M \pm S E$, mean \pm standard error of 5 determinations).

\begin{tabular}{|l|c|c|c|c|}
\hline $\begin{array}{c}\text { Station } \\
\text { Season }\end{array}$ & Abu-Qir & El-Anfushi & El-Mex & M \pm SE \\
\hline Autumn & $0.067 \pm 0.009$ & $0.065 \pm 0.007$ & $0.111 \pm 0.012$ & $0.081 \pm 0.009$ \\
\hline Winter & $0.048 \pm 0.001$ & $0.048 \pm 0.004$ & $0.086 \pm 0.003$ & $0.061 \pm 0.007$ \\
\hline Spring & $0.052 \pm 0.005$ & $0.052 \pm 0.005$ & $0.094 \pm 0.002$ & $0.066 \pm 0.007$ \\
\hline Summer & $0.064 \pm 0.002$ & $0.060 \pm 0.008$ & $0.109 \pm 0.012$ & $0.078 \pm 0.009$ \\
\hline M \pm SE & $0.058 \pm 0.003$ & $0.056 \pm 0.003$ & $0.100 \pm 0.005$ & $\frac{\mathrm{A}}{\mathrm{B}}$ \\
\hline
\end{tabular}


Table (7): Seasonal variations in Cd concentration $(\mu \mathrm{g} / \mathrm{gm})$ in whole soft tissues of Patella caerulea collected from rocky shores of three stations in Alexandria during Autumn 2001 to Summer 2002. (A-B, sequence of total $C d$ concentration means at different stations and seasons: $M \pm S E$, mean \pm standard error of 3-5 determinations).

\begin{tabular}{|c|c|c|c|c|}
\hline $\begin{array}{l}\text { Station } \\
\text { Seasom }\end{array}$ & Abu-Qir & El-Anfushi & El-Mex & $\overline{\mathrm{M} \pm \mathrm{SE}}$ \\
\hline Autumn & $0.697 \pm 0.022$ & $0.696 \pm 0.027$ & $0.850 \pm 0.030$ & $0.748+0.029$ \\
\hline Winter & $0.384 \pm 0.015$ & $0.485 \pm 0.048$ & $0.604 \pm 0.021$ & $0.524+0.025$ \\
\hline Spring & $0.654 \pm 0.031$ & $0.655 \pm 0.026$ & $0.762 \pm 0.006$ & $0.691 \pm 0.022$ \\
\hline Summer & $0.683 \pm 0.030$ & $0.677 \pm 0.023$ & $0.800 \pm 0.121$ & $0.720 \pm 0.042$ \\
\hline $\mathrm{M} \pm \mathrm{SE}$ & $\frac{0.630 \pm 0.028}{B}$ & $\frac{0.628 \pm 0.029}{B}$ & $0.754 \frac{ \pm}{A}=039$ & $0.671 \pm 0.021$ \\
\hline
\end{tabular}

Table (8): Seasonal variations in Co concentration $(\mu \mathrm{g} / \mathrm{ml})$ of sea water surface at three stations in Alexandria during Autumn 2001 to Summer 2002. (A-B, sequence of total Co concentration means at different stations and seasons: $\mathrm{M} \pm \mathrm{SE}$, mean \pm standard error of 3-5 determinations).

\begin{tabular}{|c|c|c|c|c|}
\hline $\begin{array}{ll}\text { Station } \\
\text { Season }\end{array}$ & $\overline{\mathrm{Abu}} \mathrm{Q}$ ir & El-Anfushi & EI-Mex & $\bar{M} \pm \mathrm{SE}$ \\
\hline Autumn & $0.064 \pm 0.002$ & $0.064 \pm 0.006$ & $0.047 \pm 0.002$ & $\begin{array}{c}0.058 \pm 0.003 \\
B\end{array}$ \\
\hline Winter & $0.080 \pm 0.006$ & $0.082 \pm 0.008$ & $0.069 \pm 0.013$ & $0.077 \pm 0.005$ \\
\hline Spring & $0.067 \pm 0.005$ & $0.078 \pm 0.003$ & $0.060 \pm 0.003$ & $\begin{array}{c}0.068 \pm 0.003 \\
\mathrm{AB}\end{array}$ \\
\hline Summer & $0.069 \pm 0.001$ & $0.069 \pm 0.002$ & $0.056 \pm 0.003$ & $\begin{array}{c}0.065 \pm 0.002 \\
A B\end{array}$ \\
\hline $\mathrm{M} \pm \mathrm{SE}$ & $\begin{array}{c}0.070 \pm 0.003 \\
A B\end{array}$ & $0.073+0.003$ & $\frac{0.058+0.004}{B}$ & $0.067 \pm 0.002$ \\
\hline
\end{tabular}


Table (9): Seasonal variations in Co concentration $(\mu \mathrm{g} / \mathrm{gm})$ in whole soft tissues of Patella caerulea collected from rocky shores of three stations in Alexandria during Autumn 2001 to Summer 2002. (A-B, sequence of total Co concentration means at different stations; $M \pm S E$, mean \pm standard error of ( $3-5$ determinations)

\begin{tabular}{|l|c|c|c|c|}
\hline Season Station & Abu-Qir & El-Anfushi & El-Mex & M \pm SE \\
\hline Autumn & $0.57 \pm \pm 0.101$ & $1.109 \pm 0.399$ & $0.767 \pm 0.108$ & $0.817 \pm 0.146$ \\
\hline Winter & $0.975 \pm 0.131$ & $1.650 \pm 0.550$ & $1.041 \pm 0.197$ & $1.222 \pm 0.203$ \\
\hline Spring & $0.791 \pm 0.112$ & $1.330 \pm 0.390$ & $0.944 \pm 0.173$ & $1.022 \pm 0.150$ \\
\hline Summer & $0.607 \pm 0.117$ & $1.195 \pm 0.440$ & $0.836 \pm 0.141$ & $0.879 \pm 0.162$ \\
\hline M \pm SE & $0.737 \pm 0.069$ & $\begin{array}{c}1.321 \pm 0.201 \\
\mathrm{~A}\end{array}$ & $\begin{array}{c}0.897 \pm 0.074 \\
\mathrm{AB}\end{array}$ & $0.985 \pm 0.084$ \\
\hline
\end{tabular}

Table (10): Seasonal variations in Cu concentration $(\mu \mathrm{g} / \mathrm{ml})$ of sea water surface at three stations in Alexandria during Autumn 2001 to Summer 2002. (A-C. sequence of total $\mathrm{Cu}$ concentration means at different stations and seasons: $M \pm S E$. mean \pm standard error of (3-5 determinations).

\begin{tabular}{|c|c|c|c|c|}
\hline $\begin{array}{l}\text { Station } \\
\text { Season }\end{array}$ & Abu-Qir & El-Anfushi & El-Mex & $\mathrm{M}+\mathrm{SE}$ \\
\hline Aufumn & $0.071 \pm 0.003$ & $0.073 \pm 0.001$ & $0.073 \pm 0.004$ & $\frac{0.072 \pm 0.002}{C}$ \\
\hline Winter & $0.072 \pm 0.004$ & $0.081 \pm 0.008$ & $0.082 \pm 0.002$ & $\begin{array}{c}0.078 \pm 0.003 \\
B C\end{array}$ \\
\hline Spring & $0.076 \pm 0.008$ & $0.087 \pm 0.002$ & $0.087 \pm 0.001$ & $\begin{array}{c}0.083 \pm 0.003 \\
A B\end{array}$ \\
\hline Summer & $0.083 \pm 0.005$ & $0.091 \pm 0.005$ & $0.090 \pm 0.002$ & $\frac{0.088 \pm 0.002}{A}$ \\
\hline $\begin{array}{c}\mathrm{M} \pm \mathrm{SE} \\
=\end{array}$ & $\frac{0.076 \pm 0.003}{B}$ & $0.083 \pm 0.003$ & $0.083 \pm 0.002$ & $0.081 \pm 0.002$ \\
\hline
\end{tabular}


Table (11): Seasonal variations in $\mathrm{Cu}$ concentration $(\mu \mathrm{g} / \mathrm{gm})$ in whole soft tissues of Putella caerulea collected from rocky shores of three stations in Alexandria during Autumn 2001 to Summer 2002. (A-B, sequence of $\mathrm{Cu}$ concentration means at different stations; $\mathrm{M} \pm \mathrm{SE}$, mean \pm standard error of ( $3-5$ determinations).

\begin{tabular}{|l|c|c|c|c|}
\hline Season & Abu-Qir & El-Anfushi & El-Mex & M \pm SE \\
\hline Autumn & $3.576 \pm 0.212$ & $2.42 \pm \pm 0.244$ & $6.974 \pm 0.640$ & $4.325 \pm 0.71+$ \\
\hline Winter & $4.340 \pm 0.202$ & $3.358 \pm 0.324$ & $8.224 \pm 0.095$ & $5.307 \pm 1.626$ \\
\hline Spring & $5.146 \pm 0.312$ & $3.897 \pm 0.055$ & $9.121 \pm 0.994$ & $6.054 \pm 0.843$ \\
\hline Summer & $6.196 \pm 0.148$ & $4.735 \pm 0.300$ & $9.989 \pm 0.834$ & $6.974 \pm 0.825$ \\
\hline M \pm SE & B & B & A & \\
\hline
\end{tabular}

Table (12): Seasonal variations in Fe concentration $(\mu \mathrm{g} / \mathrm{ml})$ of sea water surface at three stations in Alexandria during Autumn 2001 to Summer 2002. (a-e, sequence of Fe concentrations and A-C. sequence of total means at different stations and seasons; M+SE, mean + standard error of 3-5 determinations ).

\begin{tabular}{|c|c|c|c|c|}
\hline Season Station & Abu-Qir- & El-Anfushi & El-Mex & $\mathrm{M} \pm \mathrm{SE}$ \\
\hline Autumn & $\begin{array}{c}0.077 \pm 0.006 \\
\mathrm{bc}\end{array}$ & $0.035 \pm 0.008$ & $0.042 \pm 0.004$ & $0.051 \pm 0.007$ \\
\hline Winter & $\begin{array}{c}0.050 \pm 0.002 \\
\text { cde }\end{array}$ & $\frac{0.024+0.011}{\mathrm{e}}$ & $0.038 \pm 0.013$ & $0.037 \pm 0.006$ \\
\hline Spring & $\begin{array}{c}0.165 \pm 0.022 \\
a\end{array}$ & $\begin{array}{c}0.062 \pm 0.002 \\
\mathrm{~cd}\end{array}$ & $\begin{array}{c}0.079 \pm 0.005 \\
\mathrm{bc}\end{array}$ & $\frac{0.102 \pm 0.017}{\mathrm{~A}}$ \\
\hline Summer & $0.095 \pm 0.002$ & $\begin{array}{c}0.054 \pm 0.002 \\
\mathrm{~cd}\end{array}$ & $\begin{array}{c}0.063 \pm 0.003 \\
\mathrm{~cd}\end{array}$ & $0.07 \frac{1 \pm 0.006}{B}$ \\
\hline$M \pm S E$ & $0.097 \pm 0.014$ & $\frac{0.044+0.005}{B}$ & $\frac{0.056 \pm 0.006}{B}$ & $0.065 \pm 0.006$ \\
\hline
\end{tabular}


Table (13): Seasonal variations in Fe concentration $(\mu \mathrm{g} / \mathrm{gm})$ in whole soft tissues of Patla caerulea collected from rocky shores of three stations in Alexandria during Autumn 2001 to Summer 2002. (A-B, sequence of total $\mathrm{Fe}$ concentration means at different stations; $M \pm S E$, mean \pm standard error of 3-5 determinations ).

\begin{tabular}{|l|c|c|c|c|}
\hline $\begin{array}{c}\text { Station } \\
\text { Season }\end{array}$ & Abu-Qir & El-Anfushi & El-Mex & M \pm SE \\
\hline Autumn & $220.498 \pm 17.306$ & $233.591 \pm 8.810$ & $181.588 \pm 22.768$ & $211.892 \pm 11.0+4$ \\
\hline Winter & $205.875 \pm 12.477$ & $223.517 \pm 12.484$ & $185.262 \pm 25.575$ & $204.885 \pm 10.536$ \\
\hline Spring & $231.809 \pm 8.329$ & $252.293 \pm 7.884$ & $197.546 \pm 26.731$ & $227.216 \pm 11.587$ \\
\hline Summer & $225.329 \pm 8.658$ & $236.706 \pm 6.647$ & $186.668 \pm 23.871$ & $216.235 \pm 10.712$ \\
\hline M \pm SE & $\begin{array}{c}220.878 \pm 5.961 \\
\text { A }\end{array}$ & $\begin{array}{c}236.527 \pm 5.014 \\
\text { A }\end{array}$ & $\begin{array}{c}187.766 \pm 10.718 \\
\text { B }\end{array}$ & $215.057 \pm 5.495$ \\
\hline
\end{tabular}

Table (14): Seasonal variations in $\mathrm{Pb}$ concentration $(\mu \mathrm{g} / \mathrm{ml})$ of sea water surface at three stations in Alexandria diring Autumn 2001 to Summer 2002. (A-B. sequence of total $\mathrm{Pb}$ concentration means at differemt stations and seasons; $\mathrm{M} \pm \mathrm{SE}$, mean \pm standard error of 3-5 determinations ).

\begin{tabular}{|c|c|c|c|c|}
\hline Scason $\quad$ Station & Abu-Qir & El-Anfushi & El-Mex & $\mathrm{M} \pm \mathrm{SE}$ \\
\hline Autumn & $0.239 \pm 0.042$ & $0.439 \pm 0.254$ & $1.281 \pm 0.084$ & $\frac{0.653 \pm 0.178}{A}$ \\
\hline Winter & $0.189 \pm 0.033$ & $0.300 \pm 0.177$ & $0.784 \pm 0.094$ & $\frac{0.425 \pm 0.109}{B}$ \\
\hline Spring & $0.084 \pm 0.006$ & $0.205 \pm 0.084$ & $0.634 \pm 0.026$ & $\frac{0.308 \pm 0.087}{B}$ \\
\hline Summer & $0.149 \pm 0.052$ & $0.226 \pm 0.106$ & $0.661 \pm 0.204$ & $\frac{0.345+0.105}{B}$ \\
\hline $\mathrm{M} \pm \mathrm{SE}$ & $\frac{0.165 \pm 0.023}{B}$ & $\frac{0.293 \div 0.077}{B}$ & $\frac{0.840 \pm 0.094}{\mathrm{~A}}$ & $0.433 \pm 0.064$ \\
\hline
\end{tabular}


Table (15): Seasonal variations in $\mathrm{Pb}$ concentration $(\mu \mathrm{g} / \mathrm{gm})$ in whole soft tissues of Palles caerulea collected from rocky shores of three stations in Alexandria during Autumn 200l to Summer 2002. (a-f, sequence of $\mathrm{Pb}$ concentrations and $\mathrm{A}-\mathrm{C}$. sequence of total means at different stations and seasons: $M \pm S E$. mean \pm standard error of 3-5 determinations ).

\begin{tabular}{|c|c|c|c|c|}
\hline Season & Abu-Qir & El-Anfushí & EI-Mex & $M \pm S E$ \\
\hline Autumn & $1.820 \pm 0.114$ & $2.801 \div 0.048$ & $\frac{3.553 \pm 0.122}{\mathrm{a}}$ & $2.725 \pm 0.256$ \\
\hline Winter & $0.840 \pm 0.030$ & $1.907 \pm 0.068$ & $2.821 \div 0.167$ & $1.856 \pm 0.291$ \\
\hline Spring & $0.532 \pm 0.078$ & $1.02+\frac{ \pm 0.012}{\mathrm{de}}$ & $1.85 y+0.073$ & $\frac{1.139 \div 0.196}{\mathrm{C}}$ \\
\hline Summer & $0.554 \frac{ \pm 0.038}{\mathrm{f}}$ & $1.158 \pm 0.097$ & $\frac{1.985 \pm 0.112}{c}$ & $1.232 \pm 0.212$ \\
\hline $\bar{M} \pm \mathrm{SE}$ & $\frac{0.936+0.161}{\mathrm{C}}$ & $1.723+0.215$ & $2.555 \pm 0.213$ & $1.738 \div 0.157$ \\
\hline
\end{tabular}

Table (16): Seasonal variations in $\mathrm{Zn}$ concentration $(\mu \mathrm{g} / \mathrm{ml})$ of sea water surface at three stations in Alexandria during Autumn 2001 to Summer 2002. (A-C, sequence of total $\mathrm{Zn}$ concentration means at different stations and seasons: $M \pm S E$, mean \pm standard error of 3-5 determinations ).

\begin{tabular}{|l|c|c|c|c|}
\hline Season Station & Abu-Qir & El-Anfushi & El-Mex & M \pm SE \\
\hline \multicolumn{1}{|c|}{ Autumn } & $0.089 \pm 0.001$ & $0.089 \pm 0.005$ & $0.073 \pm 0.004$ & $\begin{array}{c}0.08 \pm \pm 0.003 \\
\mathrm{BC}\end{array}$ \\
\hline Winter & $0.069 \pm 0.005$ & $0.076 \pm 0.001$ & $0.056 \pm 0.003$ & $\begin{array}{c}0.067 \pm 0.003 \\
\mathrm{C}\end{array}$ \\
\hline Spring & $0.113 \pm 0.019$ & $0.124 \pm 0.029$ & $0.085 \pm 0.003$ & $\begin{array}{c}0.107 \pm 0.012 \\
\mathrm{AB}\end{array}$ \\
\hline Summer & $0.127 \pm 0.023$ & $0.148 \pm 0.018$ & $0.093 \pm 0.004$ & $0.123 \pm 0.012$ \\
& & & & $\mathrm{~A}$ \\
\hline $\mathrm{M} \pm \mathrm{SE}$ & $\begin{array}{c}0.099 \pm 0.009 \\
\mathrm{AB}\end{array}$ & $\begin{array}{c}0.109 \pm 0.011 \\
\mathrm{~A}\end{array}$ & $0.077 \pm 0.005$ & $0.095 \pm 0.005$ \\
\hline
\end{tabular}


Table (17): Seasonal variations in $\mathrm{Zn}$ concentration ( $\mu \mathrm{g} / \mathrm{gm}$ ) in whole soft tissues of Patella caerulea collected from rocky shores of three stations in Alexandria during Autumn 2001 to Summer 2002. (A-C. sequence of total $\mathrm{Zn}$ concentration means at different stations and seasons; $M \pm S E$, mean \pm standard error of (3-5 determinations ).

\begin{tabular}{|c|c|c|c|c|}
\hline Seasons & Abu-Qir & El-Anfushi & El-Mex & $\mathrm{M} \pm \mathrm{SE}$ \\
\hline Autumn & $19.129 \pm 0.419$ & $15.088+0.346$ & $23.170 \pm 1.323$ & $19.129 \pm 1.237$ \\
\hline Winter & $18.18 i \pm 2.075$ & $13.720 \pm 0.117$ & $19.408 \pm 2.994$ & $\frac{17.103 \pm 1.362}{C}$ \\
\hline Spring & $21.189 \pm 0.100$ & $19.764 \pm 0.105$ & $24.236 \pm 0.548$ & $21.730 \pm 0.679$ \\
\hline Summer & $27.462 \pm 0.867$ & $22.088 \pm 0.666$ & $30.836 \pm 0.529$ & $\frac{26.796 \pm 1.321}{A}$ \\
\hline $\mathrm{M} \pm \mathrm{SE}$ & $\frac{21.490 \pm 1.194}{B}$ & $\frac{17.665 \pm 1.037}{C}$ & $24.413+1.434$ & $21.189 \pm 0.834$ \\
\hline
\end{tabular}


Table (18): Trace metal concentrations ( $\mu \mathrm{g} \mathrm{g}^{-1}$ ) in the soft parts of $P$. caerulea determined in present work and in Patella sp. From mediterranean sea and other geograhpical locations.

\begin{tabular}{|c|c|c|c|c|c|c|}
\hline & $\overline{C d}$ & $\mathrm{Cu}$ & $\mathrm{Fe}$ & $\overline{Z n}$ & $\mathrm{Co}$ & References \\
\hline Patella caerulea & 0.6 & 5.76 & 215 & 21.2 & 0.9 & present work \\
\hline Patellacaendea Follonica Bay & 0.8 & 7.7 & 103 & 63 & 2.4 & $\begin{array}{l}\text { Bargagli el al.. } \\
\text { (1985) }\end{array}$ \\
\hline $\begin{array}{l}\text { Pale/la vulgala (Alexandria } \\
\text { water) domestic sewage }\end{array}$ & 0.4 & 20.9 & 450 & 38 & & $\begin{array}{c}\text { El- Rayis and Ezzat. } \\
\text { (1986) }\end{array}$ \\
\hline $\begin{array}{l}\text { Patella vilgata (Alexandria } \\
\text { water) domestic sewage }\end{array}$ & 0.5 & 20.7 & 504 & 38 & & $\begin{array}{c}\text { El- Rayis and Ezzat. } \\
\text { (1986 }\end{array}$ \\
\hline $\begin{array}{l}\text { Patella vilgata (Alexandria } \\
\text { water) industrial sewage }\end{array}$ & 0.9 & 22.9 & 1239 & 63 & & $\begin{array}{c}\text { El- Rayis and Ezzat, } \\
\text { (1986 }\end{array}$ \\
\hline $\begin{array}{l}\text { Patella aspra } \\
\text { South coast of Portugai (clean } \\
\text { site) }\end{array}$ & 0.6 & 6.1 & 1022 & 62.3 & 4.3 & Cravo et al.. (2003) \\
\hline $\begin{array}{l}\text { Patella aspra } \\
\text { South coast of Portugal } \\
\text { (contaminated site) }\end{array}$ & 1.6 & 8.1 & 1466 & 129 & 4.1 & Cravo el al., (2003) \\
\hline $\begin{array}{l}\text { Patclla sp. } \\
\text { (Turkish coast, sewage } \\
\text { influence) }\end{array}$ & 2.5 & 1.4 & 891 & 44.8 & & Ramelow (1985) \\
\hline $\begin{array}{l}\text { Parella sp. } \\
\text { (Turkish coast, not influence } \\
\text { by sewage) }\end{array}$ & 1.1 & 3.1 & 929 & 40 & & Ramelow (1985) \\
\hline $\begin{array}{l}\text { Range of metal concentrations } \\
\text { in the soft parts of molluscs }\end{array}$ & $1-5$ & $\begin{array}{l}3- \\
12\end{array}$ & $\begin{array}{l}110- \\
5000\end{array}$ & $\begin{array}{l}50- \\
500\end{array}$ & $1-3$ & $\begin{array}{l}\text { Depledige et al.. } \\
\text { (1994) }\end{array}$ \\
\hline
\end{tabular}



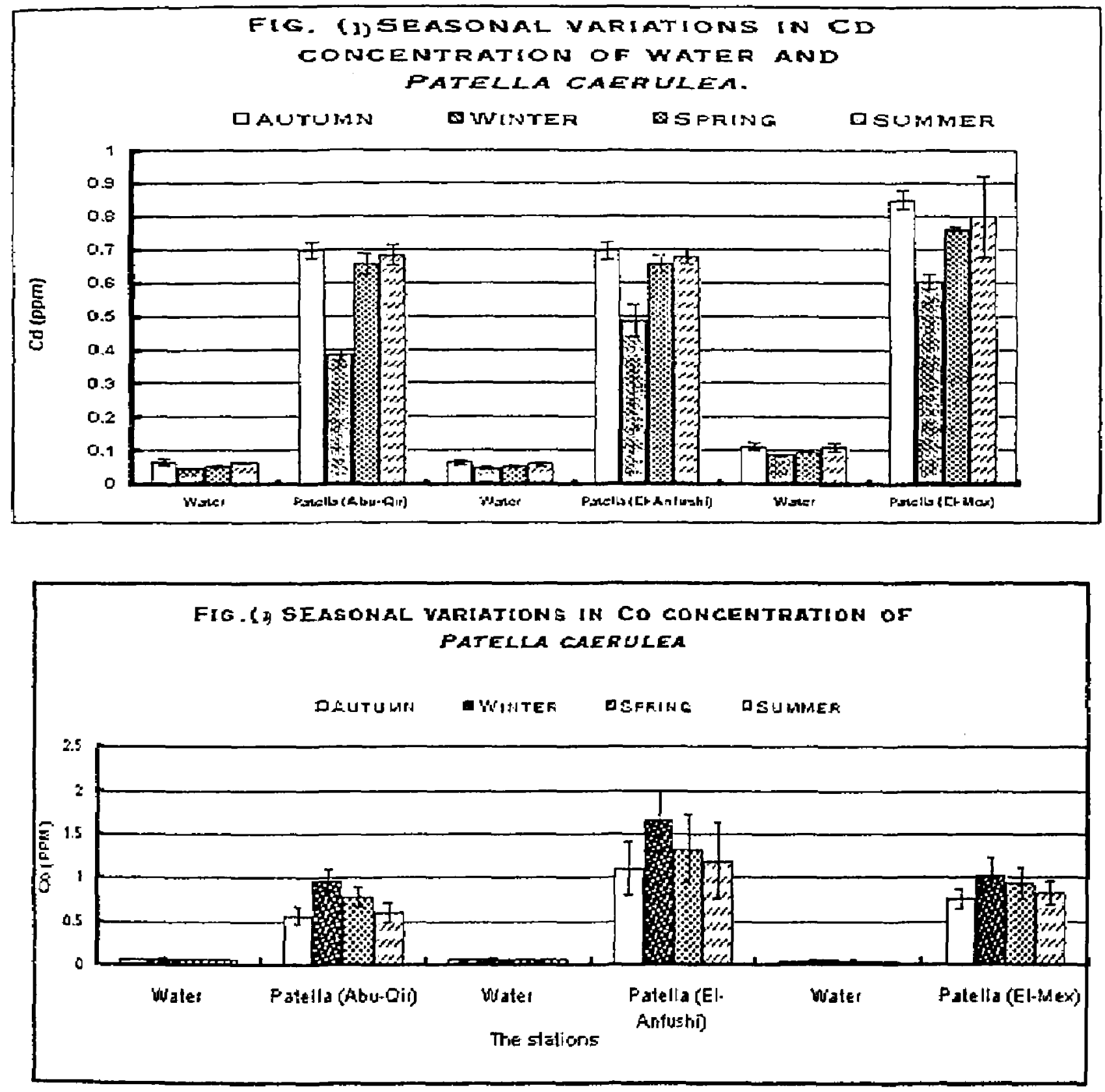

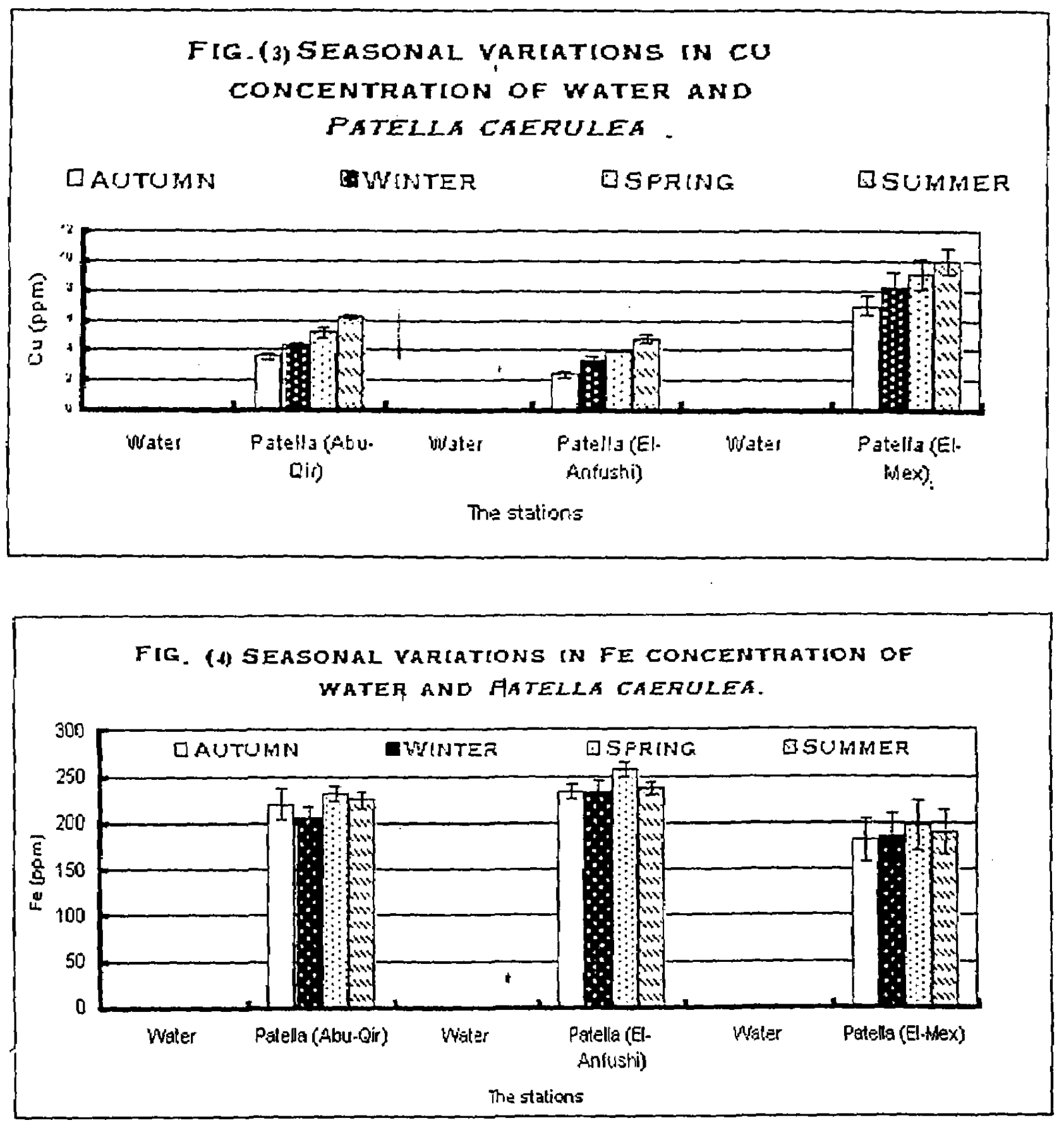

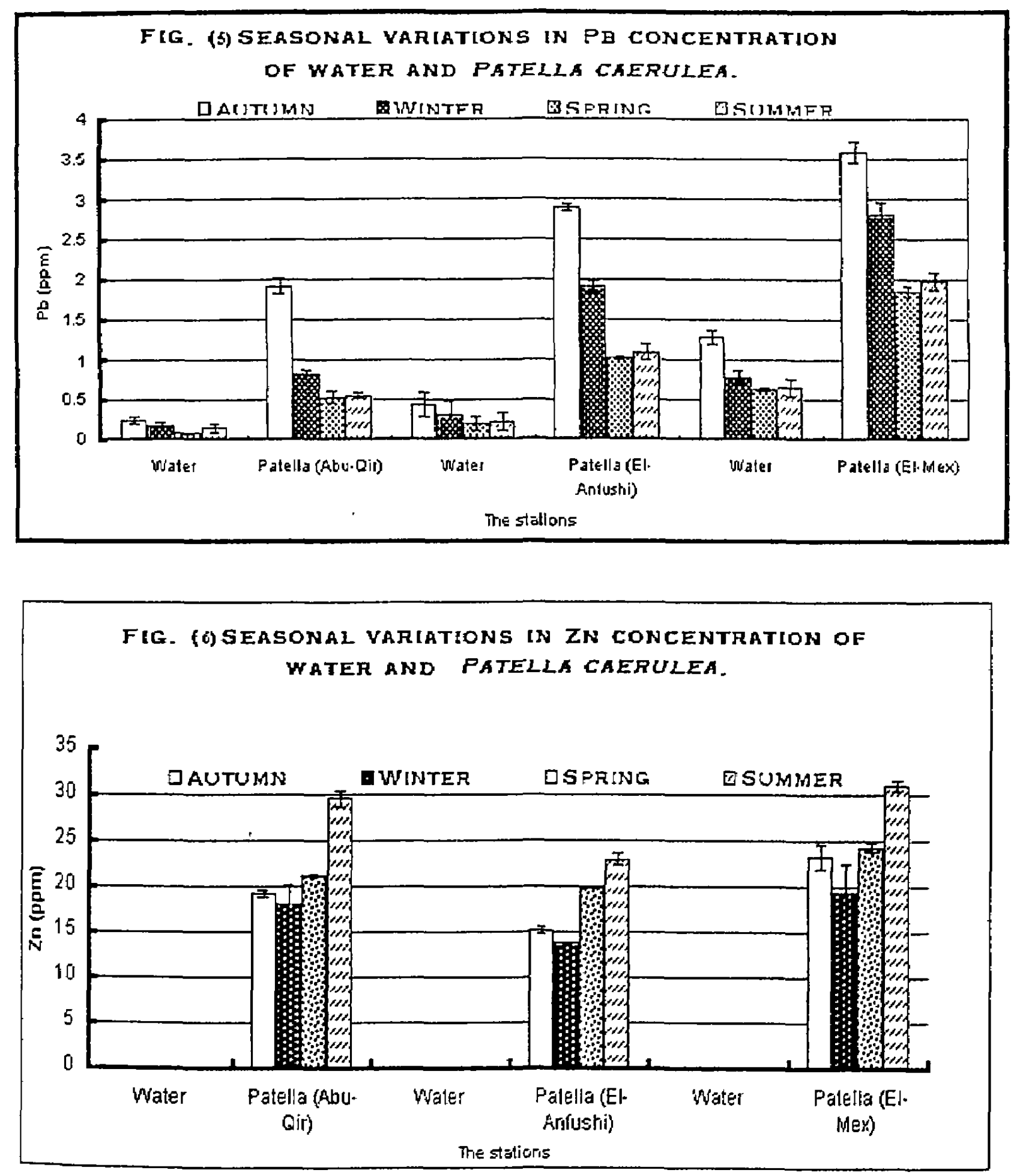